\title{
First molecular-based detection study of Leishmania infantum in the Tapirapé indigenous population in the Brazilian Amazon
}

\author{
D.S.C. Freitas ${ }^{1 \oplus}$, R.E. Silva ${ }^{3 \oplus}$, J.O.J. Costa $^{3 \oplus}$, D.V. Markus ${ }^{1 \oplus}$, H.S. Soares ${ }^{2,3 \oplus}$, A.H.H. Minervino ${ }^{4 \oplus}$, \\ J.T.R. Lima ${ }^{3 \oplus}$, S.M. Gennari ${ }^{2,3}$, and A. Marcili ${ }^{2,30 凶}$ \\ ${ }^{1}$ Faculdade de Medicina, Universidade de Santo Amaro, São Paulo, SP, Brasil \\ ${ }^{2}$ Programa de Pós-Graduação em Medicina Animal, Bem Estar e Saúde, Universidade de Santo Amaro, São Paulo, SP, Brasil \\ ${ }^{3}$ Laboratório de Doenças Parasitárias, Departamento de Medicina Veterinária Preventiva e Saúde Animal, Faculdade de Medicina \\ Veterinária e Zootecnia, Universidade de São Paulo, São Paulo, SP, Brasil \\ ${ }^{4}$ Laboratório de Sanidade Animal, Universidade Federal do Oeste Pará, Santarém, PA, Brasil
}

\begin{abstract}
Species of the genus Leishmania parasitize mammals and have life cycles that alternate between vertebrate and invertebrate hosts. Most species develop in a hematophagous arthropod and infect a specific vertebrate host that may belong to diverse orders and families. Visceral leishmaniasis is a chronic zoonosis with a wide geographic distribution, affecting 350 million people globally, mostly in areas with a high risk of infection. In Brazil, this disease not only has a high incidence but is also expanding to new areas, both in urban centers and rural areas, including territories with tribal communities, due to increasing human intervention. The objective of this study was to perform cathepsin L-like gene-based molecular diagnosis of Leishmania infantum in the indigenous Tapirapé ethnic group in the state of Mato Grosso. From the 372 individuals assessed, only $0.8 \%$ (3/372) tested positive for $L$. infantum, all from the same village (Urubu Branco). Despite the small number of infected individuals, this study demonstrates the first human cases of Leishmania infantum infection in this population, suggesting the need for regular monitoring of visceral leishmaniasis in the area and leading to a broad discussion on the planning and implementation of public health measures for the indigenous population, while respecting their distinctive territories and culture.
\end{abstract}

Key words: Phlebotominae; Confresa; Tapi'itãwa; PCR; Amazonia

\section{Introduction}

Visceral leishmaniasis is classified as a zoonosis and is a neglected tropical disease with an estimated incidence of 50,000 to 90,000 new cases per year according to the World Health Organization (WHO). More than $90 \%$ of the cases are concentrated in only ten countries worldwide, including Ethiopia, Eritrea, India, Iraq, Kenya, Nepal, Somalia, South Sudan, Sudan, and Brazil $(1,2)$.

Leishmaniasis is caused by Leishmania infantum $(3,4)$, and the transmission cycle involves a sand fly vector belonging to the Lutzomyia genus of Phlebotominae subfamily (5) and a variety of vertebrate hosts. The domestic dog is the main reservoir, and wild mammals such as marsupials, bats, horses, and felines are hosts of secondary epidemiological importance (6-11).

In this multifactorial epidemiological context, the disease is prevalent throughout Brazil, affecting many states and different biomes (12). In absolute numbers, the northeast region of Brazil has the highest concentration of cases, but attention must be paid to frequently expanding areas with new cases, which bring transmission circuits closer to urban areas $(13,14)$.

The rapid advance of the disease, however, is not restricted to large urban centers and metropolitan areas. The same occurs in the countryside, where anthropic interventions are mainly related to agriculture, cattle ranching activities, and mining, causing drastic changes in the landscape and topography $(15,16)$.

In recent years, amidst these various epidemiological elements involved in the understanding of visceral leishmaniasis, it has become apparent that the "indigenous population" comprises an extremely neglected portion of the population in Brazil. Indigenous health care was planned with the creation of the National Policy for Indigenous Health Care in 1999, in conjunction with the provisions of Law 9.836, of September 23, 1999, which 
adopted a biomedical-scientific model of health promotion. The organizational chart of this support network foresees that villages provide basic care, whereas medium and high complexity care is directed to and supported by the Indigenous Health Care Homes (CASAI). However, there is a discontinuity of these services because of multiple factors, notably language and cultural differences, geographical barriers, acceptance of professional services by only a proportion of the natives, and problems with the financial maintenance of this network. Furthermore, the discontinuity of public policies aimed at indigenous populations results in high rates of morbidity and mortality, especially with regard to infectious and parasitic diseases (17-19).

The constant and increasing anthropic interference in indigenous territories, together with a series of interruptions in epidemiological investigations resulting from discontinuity in planning, implementation, and effectiveness of public policies on primary health care that respect the cultural and logistical issues of these populations, ultimately increase the chances of epidemic outbreaks, as has been observed with other infectious diseases (20-24).

The aim of this study was to describe the prevalence of Leishmania infantum infections in the indigenous population of Tapirapé, in the Brazilian Amazon, in order to obtain new epidemiological information.

\section{Material and Methods}

The study was conducted after approval by the Research Ethics Committee of the National Indian Foundation (FUNAI; protocol number 08620.002433/2007990).

The Urubu Branco indigenous land, inhabited by the Tapirapé people of the Tupi-Guarani linguistic family, was selected for this study. This reserve of 168,000 hectares is located in an area of the legal Amazon that includes seven villages: Urubu Branco (1040'16.1"S, 51²1'13.8"W), Sapeva $\left(10^{\circ} 48^{\prime} 12.2^{\prime \prime S}, 5^{\circ} 17^{\prime} 12.8^{\prime \prime W}\right)$, Córrego da Onça (1042'27.5"S, 5118'49.0"W), Buriti II (10³9'33.6"S, $\left.51^{\circ} 17^{\prime} 41.2^{\prime \prime W}\right)$, Codebra (1052'09.6"S, 5115'37.8"W), Xexéu (1051'20.6"S, 51'18'19.8"W), and Santa Laura $\left(10^{\circ} 36^{\prime} 23.9^{\prime \prime} \mathrm{S}, 51^{\circ} 10^{\prime} 47.9^{\prime \prime} \mathrm{W}\right)$ distributed in the municipalities of Confresa, Porto Alegre do Norte, and Santa Terezinha in the northeast of Mato Grosso state in the central-west region of Brazil.

Blood samples were collected from volunteers in the reserve who were over three years of age. The samples included 212, 63, 44, 32, 17, and 4 individuals from Urubu Branco, Santa Laura, Córrego da Onça, Sapeva, Codebra, and Buriti II, respectively, totaling 372 individuals.

Whole-blood samples were collected using EDTA as an anticoagulant in vacuum tubes, stored as frozen subaliquots in plastic microtubes at $-20^{\circ} \mathrm{C}$, and sent to the laboratory. DNA was extracted from the blood samples using the commercial PureLink ${ }^{\circledR}$ Genomic DNA Mini Kit
(Thermo Fisher, USA), followed by spectrophotometric quantification to verify the extraction efficiency.

For specific molecular diagnosis of Leishmania infantum, PCR was performed using cathepsin L-like gene (7).

\section{Results}

Of the 372 indigenous individuals tested, the molecular diagnosis revealed three positive samples, corresponding to a percentage of $0.8 \%(3 / 372)$. Two positive samples were from females and one from a male, aged between 17 and 37 years, all residents of Urubu Branco.

\section{Discussion}

This study reports for the first time infections by Leishmania infantum in the Tapirapé indigenous population assessed by molecular tests, confirming the circulation of $L$. infantum in this population. A previous study indicated that the occurrence of antibodies anti-Leishmania in the canine population residing in these villages was greater than $8 \%$, but in humans, only two samples presented reactive results to $L$. amazonensis (25). The different serological tests used may vary in sensitivity and specificity, depending on the method (26). Importantly, the higher percentage in dogs and human reaction to $L$. amazonensis may be due to discrepancies in these serological tests, such as specificity failures that induce serum cross-reactivity phenomena $(27,28)$ and the molecular diagnosis based on cathepsin L-like being specific to L. infantum (7).

Methodology, type of antigen used, time of infection, and host characteristics directly influence the performance of serological testes (26). Thus, the use of molecular tools with high sensitivity and specificity are more effective in assisting the development of public health policies.

Entomological surveys conducted in indigenous villages in the state of Mato Grosso show the presence of species of sand flies that are important vectors of Leishmania infantum, notably Lutzomyia longipalpis and Lutzomyia cruzi (29), suggesting that these species are also present around Urubu Branco Indigenous Land. Among the villages studied, this is the one with the highest population density and has also experienced many anthropic interferences, resulting in many ecological tensions that favor these vector species, which explains all the epidemiological elements necessary to maintain the transmission chain identified in this study.

Various authors suggest that the increasing occurrence of these vector species in indigenous areas is the result of social tensions faced by these populations, triggered by economic activities that threaten the integrity of their territories, fragment natural space, and disrupt systems of ethnic and social organization, resulting in migration and displacement $(29,30)$. These episodes of fragmentation are of particular concern because they 
allow the expansion of areas of direct interaction between forest ecotopes and peri-domiciles of low health security, in addition to providing pathways for the dispersion of positive dogs between different population centers.

Another element that may explain the presence of sand flies and the resulting transmission of the disease in these peri-domicile areas is the increase in the population of dogs kept either for affection reasons or subsistence hunting. In addition, extractivism and the presence of livestock, including chickens and pigs, which, although not actual hosts of the parasite, serve as blood-meal sources for insect vectors $(30,31)$.

This study suggests that specific molecular tests for Leishmania infantum may be an alternative to the serological methods commonly used and recommended by health agencies, as they are important tools for solving problems of sensitivity and specificity of serological tests (25). Therefore, this molecular diagnostic test can be efficiently used in routine diagnosis of infections in patients and in epidemiological surveys involving humans, animal hosts, and insect vectors (7).

These results, together with previous epidemiological studies on visceral leishmaniasis in indigenous populations, highlight the social vulnerabilities faced by these populations when they are exposed and issues related to marginalization of access to basic health care systems, which leads to reduced testing for chronic infectious diseases such as visceral leishmaniasis (32). Another factor that deserves particular attention is the demand for access to the formal education system, as studies suggest that schooling acts as a protective factor for various chronic infectious diseases, confirming the potential of schools as decentralized platforms for strengthening the concept of health education (33).

Additionally, it is important to consider the occurrence of infectious comorbidities such as HIV, influenza viruses, and other systemic parasites in these populations, as these diseases can lead to a direct increase in the probability of

\section{References}

1. Alvar J, Vélez ID, Bern C, Herrero M, Desjeux P, Cano J, et al. Leishmaniasis Worldwide and global estimates of its incidence. PLoS One 2012; 7: e35671, doi: 10.1371/journal. pone.0035671.

2. Desjeux P. Leishmaniasis. Public health aspects and control. Clin Dermatol 1996; 14: 417-423, doi: 10.1016/ 0738-081X(96)00057-0.

3. Pigott DM, Golding N, Messina JP, Battle KE, Duda KA, Balard Y, et al. Global database of leishmaniasis occurrence locations, 1960-2012. Sci Data 2014; 1: 140036, doi: 10.1038/sdata.2014.36.

4. Marcili A, Sperança MA, Costa AP, Madeira MF, Soares HS, Sanches CO, et al. Phylogenetic relationships of Leishmania species based on trypanosomatid barcode (SSU rDNA) and gGAPDH genes: Taxonomic revision of Leishmania (L.) occurrence and spread of visceral leishmaniasis. Effective management of these issues require health policies that consider multiple interventions in an integrated manner with contextualized initiatives that go beyond conventional medical curative prescription-based approaches (34-38).

These epidemiological parameters are affected by multiple factors, including a rapid increase in the rate of deforestation in the legal Amazon, weakening and dismantling of public policies related to sustainable indigenous development, the exacerbation of conflicts related to the demarcation of Federal indigenous reserves, and a mistaken Federal vision that opposes the protection of natural resources to economic development $(39,40)$.

In conclusion, a small number of infected individuals were found in the studied area, but as these were the first recorded human cases of Leishmania infantum infection in this locality we can draw important conclusions: 1) there is a need to adopt consistent and effective measures for monitoring visceral leishmaniasis in this area, and 2) in broader terms, there is a need to plan and implement public health policies that are appropriate to the logistical characteristics and respect the cultural components of these indigenous peoples who have inhabited these territories for centuries and thus have legitimate rights to them.

\section{Acknowledgments}

We thank our collaborators Antônio Francisco MaIheiros, Agenora Moraes da Silva, and Irenildes Cândida de Oliveira for their help in contacting the indigenous communities of Tapi'itãwa land and logistical support in collecting biological samples. This work was financially supported by FAPESP (Project 2010/50839-9), the Coordenação de Aperfeiçoamento de Pessoal de Nível Superior - Brasil (CAPES; Financial code 001), and the Conselho Nacional de Desenvolvimento Científico e Tecnológico (CNPq). infantum chagasi in South America. Infect Genet Evol 2014; 25: 44-51, doi: 10.1016/j.meegid.2014.04.001.

5. Costa AP, Costa FB, Soares HS, Ramirez DG, Mesquita ETKC, Gennari SM, et al. Trypanosoma cruzi and Leishmania infantum chagasi Infection in Wild Mammals from Maranhão State, Brazil. Vector Borne Zoonotic Dis 2015; 15: 656-666, doi: 10.1089/vbz.2015.1771.

6. Forattini OP, Rabello EX, Pattoli DGB. The finding of Lutzomyia longipalpis (Lutz and Neiva, 1912) in the State of São Paulo, Brazil. Report [in Spanish]. Rev Saude Publ 1970; 4: 99-100, doi: 10.1590/S0034-89101970000100014.

7. da Silva RE, Sampaio BM, Tonhosolo R, da Costa APR, Costa LES, Nieri-Bastos FA, et al. Exploring Leishmania infantum cathepsin as a new molecular marker for phylogenetic relationships and visceral leishmaniasis diagnosis. 
BMC Infect Dis 2019; 19: 895, doi: 10.1186/s12879-0194463-8.

8. Rocha AVVO, Moreno BFS, Cabral AD, Louzeiro NM, Miranda LM, Dos Santos VMB, et al. Diagnosis and epidemiology of Leishmania infantum in domestic cats in an endemic area of the Amazon region, Brazil. Vet Parasitol 2019; 273: 80-85, doi: 10.1016/j.vetpar.2019.08.007.

9. Courtenay O, Quinnell RJ, Garcez LM, Dye C. Low infectious ness of a wildlife host of Leishmania infantum: the crab-eating fox is not important for transmission. Parasitology 2002; 125: 407-414, doi: 10.1017/S003118 2002002238.

10. Figueiredo FB, Gremião IDF, Pereira SA, Fedulo LP, Menezes RC, Balthazar DA, et al. First report of natural infection of a bush dog (Speothos venaticus) with Leishmania (Leishmania) chagasi in Brazil. Trans $R$ Soc Trop Med Hyg 2008; 102: 200-201, doi: 10.1016/j.trstmh.2007.10.001.

11. Marcili A, da Silva RE, da Costa VP, Nieri-Bastos FA, Azevedo RCF, Moraes Filho J, et al. Canine visceral leishmaniasis in São Paulo, Brazil, the most populous city of South America: isolation, molecular diagnosis, and phylogenetic inferences. Vector Borne Zoonotic Dis 2020; 20: 768-772, doi: 10.1089/vbz.2020.2638.

12. Cunha CR, Ramos Filho AS, Lopes TB, Araújo MHM, Calandrini TSS, Neves MNSS, et al. Tipificação epidemiológica dos casos de leishmaniose visceral humana no Brasil, no período de 2013 a 2017 [in Portuguese]. Rev Eletrônica Acervo Saúde 2020; 41: 1-10.

13. Oliveira AM, López RVM, Dibo MR, Rodas LAC, Guirado MM, Chiaravalloti-Neto F. Dispersion of Lutzomyia longipalpis and expansion of visceral leishmaniasis in São Paulo State, Brazil: identification of associated factors through survival analysis. Parasit Vectors 2018; 11: 503, doi: 10.1186/s13071-018-3084-1.

14. Oliveira ALL, Paniago AMM, Dorval MEC, Oshiro ET, Leal CR, Sanches M, et al. Emergent outbreak of visceral leishmaniasis in Mato Grosso do Sul state [in Portuguese]. Rev Soc Bras Med Trop 2006; 39: 446-450, doi: 10.1590/ S0037-86822006000500005.

15. Carvalho AG, Luz JGG, Rodrigues LD, Dias JVL, Fontes CJF. Factors associated with Leishmania spp. infection in domestic dogs from an emerging area of high endemicity for visceral leishmaniasis in Central-Western Brazil. Res Vet Sci 2019; 125: 205-211, doi: 10.1016/j.rvsc.2019.06.013.

16. Langdon EJ, Diehl EE. Participação e autonomia nos espaços Interculturais de saúde indígena: reflexões a partir do sul do Brasil. Saude Soc 2007; 16: 19-36, doi: 10.1590/ S0104-12902007000200004.

17. Diehl EE, Langdon EJ, Dias-Scopel RP. Contribuição dos agentes indígenas de saúde na atenção diferenciada à saúde dos povos indígenas brasileiros. Cad Saude Publica 2012; 28: 819-831, doi: 10.1590/S0102-311X201200050 0002.

18. Dos Santos MM, Cruz KJC, de Sá LCR, Batista CC, Aguiar EMG, Nogueira AMT. Healthcare provided to Indigenous people from the Northeast Brazilian state of Maranhão by the Unified Health System in Teresina-PI in 2011: a descriptive study [in Portuguese]. Epidemiol Serv Saúde 2016; 25: 127136, doi: $10.5123 /$ S1679-49742016000100013.

19. Coimbra Jr CEA, Santos RV. Saúde, minorias e desigualdade: algumas teias de inter-relações, com ênfase nos povos indígenas no Brasil. Cienc Saude Coletiva 2000; 5: 125-132, doi: 10.1590/S1413-81232000000100011.

20. Basta PC, Coimbra Jr CEA, Escobar AL, Santos RV. Epidemiologic aspects of tuberculosis in the Suruí Indians, Brazilian Amazon [in Portuguese]. Rev Soc Bras Med Trop 2004; 37: 338-342, doi: 10.1590/S0037-868220040004 00010.

21. Malheiros AF, Mathews PD, Lemos LMS, Braga GB, Shaw JJ. Prevalence of Hymenolepis nana in Indigenous Tapirapé ethnic group from the Brazilian Amazon. Am J Biomed Res 2014; 2: 16-18, doi: 10.12691/ajbr-2-2-1.

22. Mendes AM, Leite MS, Langdon EJ, Grisotti M. The challenge of providing primary healthcare care to indigenous peoples in BrazilEl desafío de brindar atención primaria de salud a los pueblos indígenas en Brasil [in Portuguese]. Rev Panam Salud Publica 2018; 42: 1-6, doi: 10.26633/RPSP. 2018.184.

23. Marinho CC, Nicolato AJPG, Reis VW, Dos Santos RCC, Silva JC, Faria HP, et al. Ultrasound evaluation of schistosomiasis-related morbidity among the Xakriabá people in the state of Minas Gerais, Brazil. Radiol Bras 2020; 53: 7-13, doi: 10.1590/0100-3984.2019.0047.

24. Mendes AM, Lima MS, Maciel AGP, Menezes RAO, Eugênio NCC. Malaria among indigenous peoples on the Brazil-French Guiana border, 2007-2016: a descriptive study. Epidemiol Serv Saúde 2020; 29: e2019056, doi: 10.5123/s1679-49742020000200012.

25. Lima JTR, Gennari SM, Soares HS, Minervino AHH, Malheiros AF, Marques FS, et al. Serodiagnosis of visceral and cutaneous leishmaniasis in human and canine populations living in indigenous reserves in the Brazilian Amazon region. Rev Soc Bras Med Trop 2017; 50: 61-66, doi: 10.1590/0037-8682-0377-2016.

26. Freire ML, Assis TM, Oliveira E, Avelar DM, Siqueira IC, Barral A, et al. Performance of serological tests available in Brazil for the diagnosis of human visceral leishmaniasis. Plos Negl Trop Dis 2019; 13: e00007484, doi: 10.1371/ journal.pntd.0007484.

27. Vexenat AC, Santana JM, Teixeira ARL. Cross-reactivity of antibodies in human infections by the kinetoplastid protozoa Trypanosoma cruzi, Leishmania chagasi and Leishmania (Viannia) braziliensis. Rev Inst Med Trop Sao Paulo 1996; 38: 177-185, doi: 10.1590/S0036-46651996000300003.

28. Vale AM, Fujiwara RT, da Silva Neto AF, Miret JA, Alvarez DCC, da Silva JCF, et al. Identification of highly specific and cross-reactive antigens of Leishmania species by antibodies from Leishmania (Leishmania) chagasi naturally infected dogs. Zoonoses Public Health 2009; 56: 41-48, doi: 10.1111/j.1863-2378.2008.01183.x.

29. Maciel GBML, Missawa NA. Sandflies (Diptera: Psychodidae) in indigenous villages in the State of Mato Grosso [in Portuguese]. Rev Soc Bras Med Trop 2009; 42: 597-602, doi: 10.1590/S0037-86822009000500023.

30. Guerra JAO, Barros LMB, Fé NF, Guerra MVE, Castellon E, Paes MG, et al. Visceral leishmaniasis among indians of the state of Roraima, Brazil: clinical and epidemiologic aspects of the cases observed from 1989 to 1993 [in Portuguese]. Rev Soc Bras Med Trop 2004; 37: 305-311, doi: 10.1590/ S0037-86822004000400004.

31. Rêgo FD, Shimabukuro PHF, Quaresma PF, Coelho IR, Tonelli GB, Silva KMS, et al. Ecological aspects of the 
Phlebotominae fauna (Diptera: Psychodidae) in the Xakriabá indigenous reserve, Brazil. Parasit Vectors 2014; 7: 1-12, doi: 10.1186/1756-3305-7-1.

32. Gomes SC, Esperidião MA. Acesso dos usuários indígenas aos serviços de saúde de Cuiabá, Mato Grosso, Brasil. Cad Saude Publica 2017; 33: 1-20, doi: 10.1590/0102$311 \times 00132215$.

33. Graeff SVB, Pícolli RP, Arantes R, Castro VOL, Cunha RV. Epidemiological aspects of HIV infection and AIDS among indigenous populations. Rev Saude Publica 2019; 53: 71, doi: 10.11606/S1518-8787.2019053000362.

34. Sousa-Gomes ML, Maia-Elkhoury ANS, Pelissari DM, Lima Junior FEF, Sena JM, Cechinel MP. Coinfecção LeishmaniaHIV no Brasil: aspectos epidemiológicos, clínicos e laboratoriais. Epidemiol Serv Saude 2011; 20: 519-526, doi: 10.5123/S1679-49742011000400011.

35. Chidgzey PJ, Davis S, Williams P, Reeve1 C. An outbreak of influenza $A$ (H1N1) virus in a remote Aboriginal community post-pandemic: implications for pandemic planning and health service policy. Aust N Z J Public Health 2015; 39: 15-20, doi: 10.1111/1753-6405. 12295.
36. Moreno ES, Cabral JO, Freire MP, Costa AS, Costa TS, Souto RNP, et al. Abordagens alternativas para a vigilância da leishmaniose tegumentar em áreas indígenas - estudo de caso entre os Wajãpi do Amapá. Vigil Sanit Debate 2016; 4: 51-59, doi: 10.22239/2317-269X.00809.

37. Benzaken AB, Sabidó M, Brito I, Bermúdez XPD, Benzaken NA, Galbán E, et al. HIV and syphilis in the context of community vulnerability among indigenous people in the Brazilian Amazon. Int J Equity Health 2017; 16: 92, doi: 10.1186/s12939-017-0589-8.

38. Cardoso AM, Resende PC, Paixao ES, Tavares FG, Farias YN, Barreto CTG, et al. Investigation of an outbreak of acute respiratory disease in an indigenous village in Brazil: contribution of Influenza A(H1N1) pdm09 and human respiratory syncytial viroses. PLoS One 2019; 14: e0218925, doi: 10.1371/journal.pone.0218925.

39. Silva ECA. Povos indígenas e o direito à terra na realidade brasileira. Serv Soc Soc 2018; 133: 480-500, doi: 10.1590/ 0101-6628.155.

40. Marcovitch J, Pinsky V. Bioma Amazônia: atos e fatos. Estud Av 2020; 34: 83-106, doi: 10.1590/s0103-4014. 2020.34100.007. 